University of Minnesota Morris Digital Well

University of Minnesota Morris Digital Well

English Publications

Faculty and Staff Scholarship

Fall 2012

\title{
Virginia Woolf and British Russophilia
}

Michael Lackey

University of Minnesota Morris, lacke010@morris.umn.edu

Follow this and additional works at: https://digitalcommons.morris.umn.edu/eng_facpubs

Part of the Literature in English, British Isles Commons

\section{Recommended Citation}

Lackey, Michael, "Virginia Woolf and British Russophilia" (2012). English Publications. 20.

https://digitalcommons.morris.umn.edu/eng_facpubs/20

This Article is brought to you for free and open access by the Faculty and Staff Scholarship at University of Minnesota Morris Digital Well. It has been accepted for inclusion in English Publications by an authorized administrator of University of Minnesota Morris Digital Well. For more information, please contact skulann@morris.umn.edu. 


\section{Virginia Woolf and British Russophilia}

\section{Author(s): Michael Lackey}

Source: Journal of Modern Literature, Vol. 36, No. 1 (Fall 2012), pp. 150-152

Published by: Indiana University Press

Stable URL: https://www.jstor.org/stable/10.2979/jmodelite.36.1.150

JSTOR is a not-for-profit service that helps scholars, researchers, and students discover, use, and build upon a wide range of content in a trusted digital archive. We use information technology and tools to increase productivity and facilitate new forms of scholarship. For more information about JSTOR, please contact support@jstor.org.

Your use of the JSTOR archive indicates your acceptance of the Terms \& Conditions of Use, available at https://about.jstor.org/terms 


\title{
Virginia Woolf and British Russophilia
}

\author{
Michael Lackey \\ University of Minnesota, Morris
}

Roberta Rubenstein. Virginia Woolf and the Russian Point of View. New York: Palgrave Macmillan, 2009. xi, 265 pp. $\$ 80.00$.

Roberta Rubenstein convincingly demonstrates that England was infatuated with all things Russian between the years 1912 and 1922. These were some of the most formative years in the development of Woolf's writing and thinking, and consequently, Rubenstein argues that prominent Russian writers heavily influenced Woolf the writer and Woolf the critic. Given the degree to which Russian writers influenced Woolf in particular and England more generally, Rubenstein suggests that the Russian influence had a decisive impact in determining the shape of British Modernism.

Keywords: Virginia Woolf / Russophilia / British Modernism

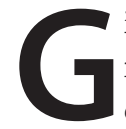
iven its title, Virginia Woolf and the Russian Point of View would seem at first glance to be an extremely narrow study, relevant only to the most committed Woolf scholars, who also have an interest in Russian history and/or literature. But nothing could be further from the truth. By intelligently documenting the degree to which Russophilia - an infatuation with Russian literature, painting, music, and ballet — swept through England, mainly from 1912 until 1922, Rubenstein convincingly demonstrates that Russian literature had a major impact not only on Woolf's thinking and writing, but also on the eventual form of British modernism more generally. This is not to say that Woolf simply adopted Russian aesthetic techniques; Rubenstein's book is no mere study of influence. Rather, Rubenstein demonstrates that Woolf, during her most formative years (1917-1922) as a writer and critic (158), internalized Russian aesthetic innovations and re-shaped them to suit her own artistic objectives. More specifically, Woolf's appropriation and subsequent transformation of Russian aesthetic techniques led her to formulate new theories about stream of consciousness, literary doubling, multiple subjectivity, and representations of the subconscious, which enabled her and her contemporaries to revolutionize the art of fiction. If Rubenstein is right - and she rallies much evidence to suggest she is - then knowledge not only of British Russophilia but also of Woolf's particular engagement and 
characterization of it is indispensable for understanding the origins of British modernism.

Rubenstein begins her study with a splendid chapter on Woolf's ambivalent response to Fyodor Dostoevsky's fiction. If “The Mark on the Wall," which is considered "the birth of Woolf's stream of consciousness technique" (23), was published in 1917, then there is good reason to think that Dostoevsky was the primary influence on that story, because Woolf published two reviews of Dostoevsky's short fiction in that same year. What Rubenstein does skillfully at this point is to illustrate how Woolf's depiction of Dostoevsky's charting of the fluid mind in rapid motion mirrors what Woolf pictures in "The Mark on the Wall." For Rubenstein, this is a crucial moment in Woolf's career and in British modernism, for the emergent conceptions of "the discontinuous mental process" (25), which Woolf would theorize most clearly in "Mr. Bennett and Mrs. Brown" (1923) and "Modern Fiction" (1925), were first formulated in her reviews of Dostoevsky's fiction. Indeed, as this study shows, we can "draw a direct line from an observation in her first review of Dostoevsky's fiction to the pivotal arguments in these essays" (29). In essence, Dostoevsky had a decisive impact on Woolf-the-critic as well as Woolf-the-artist. Given Woolf's impact on British modernism, we can, therefore, say that Dostoevsky's influence was pervasive.

Despite her debt to Dostoevsky, Woolf did have some objections to the Russian novelist's work. An excessive focus on "psychological extremity" (122), a lack of artistic control when depicting a discontinuous mind in motion (56), and a "tumultuous flux of emotions" (136) in his characters led her to express reservations about the nature and effectiveness of his aesthetic vision. This is why Rubenstein concludes that "Woolf's attitude toward Dostoevsky might be described as a kind of fascinated dissatisfaction" (56).

In stark contrast to Dostoevsky's "exaggerated emotional pitch" (56), Woolf favored an aesthetic that focused more on the quotidian, and it was Anton Chekhov and Leo Tolstoy who provided her with valuable insight. As her discontent with British narrative models increased, Woolf discovered in Chekhov's work two key ideas that enabled her to set her work apart from her Victorian and Edwardian predecessors: "Chekhov's focus on unremarkable characters engaged in inconsequential actions in stories without plots" (60) and "his indifference to tidy resolutions" (66). If "the unfolding of plot or the presentation of sharply delineated characters" was the dominant mandate imposed on pre-modern authors, then Chekhov's fiction had a liberating effect in that it emphasized "emotional tone and psychological discovery" (66), an aesthetic approach that led Woolf to conclude that modern fiction is primarily concerned with the dark places of psychology. This valorization of the psychological mundane was just as important for Tolstoy, who was able to transform "the quotidian into art" (111). But more importantly, Tolstoy's aesthetic appealed to Woolf because he was able to go one step beyond Dostoevsky. Instead of representing "his character's interiority," as Dostoevsky so brilliantly did, Tolstoy was able to depict "the mental processes that underlie" the interiority (108). 
Given her radical departure from standard narrative conventions and her construction of a totally new aesthetic, Woolf finally needed to produce innovative devices for depicting slopes of consciousness and a multiple/multiplying subjectivity. It was in the writing of Ivan Turgenev that she found the technical mastery that suited her objectives and sensibility (135). Like Woolf, Turgenev acknowledged that there are "'different I's in novel writing" (145), but to depict those multiplying and conflicting I's, the novelist must have a clear "sense of aesthetic proportion" (135) and the ability to balance the mundane facts of a story and the artist's overarching vision. Only a novelist totally consumed with a "passion for art," which is the subtitle of the Turgenev chapter, could eventually develop a suitable aesthetic to depict subtle shades of feeling and multiple layers of consciousness, and it was Turgenev who provided Woolf with a rigorous and disciplined model that helped her to master her craft.

Virginia Woolf and the Russian Point of View is a superb work of scholarship, but the title is misleading. Rubenstein accomplishes far more than the title of her book suggests. Her study would be an excellent resource for scholars of James Joyce, E.M. Forster, Aldous Huxley, D.H. Lawrence, and others. It should be in the library of all scholars of British modernism, no matter their area of specialization. 